\title{
Implementation of ISO 26000 Dan Stakeholder Engagement Strategy to Optimalizing Corporate Social Responsibility in PT. Semen Indonesia, Tuban
}

\author{
Alfiandi Imam Mawardi ${ }^{1}$, Reiga Ritomiea Ariescy ${ }^{2}$, Luky Susilowati ${ }^{3}$, \\ Pandji Soegiono ${ }^{4}$ and Supriyono ${ }^{5}$ \\ \{ alfiandi.ma@upnjatim.ac.id ${ }^{1}$ \} \\ 1,2,3,4,5 Economy and Business Faculty, Universitas Pembangunan "Veteran” Jawa Timur, Indonesia
}

\begin{abstract}
Considering the industrial growth, cement industry predicted an increase demand of cement around 6-7\% in 2014 and in 2019, the product capacity of cement will reach 90-95 million ton in Indonesia. Moreover, there is an issue which potentially make more competition between Cement Company are ASEAN Economy Community in 2017. This triggering issue is commonly affecting production unit that should build new plant for achieving capacity target. To achieving the business goal, Corporate Social Responsiblity wiil be so important to show their responsibility to environment and community to make business sustainablitity. This research will be discussed about the optimalization of Corporate Social Responsibility in PT. Semen Indonesia, Tuban. According to implementation of CSR in PT. Semen Indonesia, there are several problems happened in this company. Internal of CSR department states that CSR implementation is unoptimal, which is the low percentage of shared value within company and community always occured. To solve this problem, there are offered solutions to improve the implementation of CSR in internal and external view. Application of ISO 26000 and Stakeholder Engagement strategy used to asnwer that problem in PT. Semen Indonesia, Tuban.
\end{abstract}

Keyword: CSR, PT. Semen Indonesia (Tuban), ISO 26000, Stakaholder Engagement Strategy

\section{Introduction}

Considering the industrial growth, cement industry predicted an increase demand of cement around 6-7\% in 2014 and in 2017, the product capacity of cement will reach 90-95 million ton in Indonesia. Other issues, which potentially make more competition between Cement Company, are ASEAN Economy Community in 2015. This triggering issue is commonly affecting production unit that should build new plant for achieving capacity target.

Based on data from the Ministry of Industry, there are 9 cement companies that listed in the mining operations and approximately there are 22 big production sites in Indonesia. The main business of this industry is exploration of soil containing limestone. This exploration will certainly damage the natural balance and will definitely harm population around the production site. Therefore, the trust of the various stakeholders on business sustainability is needed. To achieve the business sustainability, especially for mining company, CSR will be so important to show their responsibility to environment and community. Particularly in the cement industry, that is very important to improve the company's image in the community and gain public support to implement meaningful and strategic CSR program. 
PT. Semen Indonesia is state-owned enterprise of Cement Company in Indonesia. As stateowned enterprise, PT. Semen Indonesia have an obligation to fulfill CSR program that is not only governed by Peraturan Perseroan Terbatas Nomer 40/2007 Bab V Artikel 74, but also governed by Peraturan Pemerintahan No.08/MBU/2013 about Partnership and Community Development Programs. To comply with all existing rules, PT Semen Indonesia required including CSR as a business process under the control of a company's independent department. It should also be reported annually on the basis of ISO 26000 as CSR's guidance program (Semen \& Sustainability, 2017).

The concept of Social and Environmental Responsibility or CSR is growing very rapidly, not merely as instruments of the company's interaction with the consumer, but the success of the CSR program will show the real face of the company. To realize the strategic steps to develop Tuban IV as part of the production area of PT. Semen Indonesia with a value of Rp 3.18 trillion and investment in production capacity of 3 million tons per year. This development needs synergy between company and stakeholders that should be happen continuously.

\section{Analysis of CSR Problem}

Based on WBCSD, Corporate Social Responsibility is business commitment to contribute to sustainable economic development working with employees, their families, the local community, and society at large to improve their quality of life. Otherwise, Many researchers have approving CSR is became one of business process that is important to develop. CSR also is not a result of financial expenses, but it relevant with social investment. As an idea, CSR requires the responsibility of company to not only focus on the financial condition. But it is clear that the CSR is the responsibility of the company to stakeholders to behave ethically, minimize negative impacts and maximize the positive impact that covers economic, social, and environmental aspects in order to achieve sustainable development goals (Alves \& Rodrigues, 2018).

Cement Industry is one of Indonesia's industries that predicted to grow significantly yearby-year. Despite of the promising industry, cement industry naturally has related with environmental exploitation and environmental destruction. With the growing demand of cement in domestic and foreign market, expanding new plant or new field is prepared to upsize the production volume. The threats of those strategies are to make sustainable development within "people, planet and profit". In order to make sustainable development to support the business process by implementing CSR or social responsibility is a good stuff that needed once today (Gussman, Fathonah, \& Wibawa, 2009). Regarding to CSR that already recognized in Indonesia at the beginning of 2008 , PT. Semen Indonesia constantly dedicated to serve community by appropriate CSR programs. For optimize CSR in Semen Gresik, Tuban, the company has operating CSR with theme "BERSINERGI- BERsama Semen Indonesia cERdaskan neGerI" that is success to implement for stakeholder. On the other hand, company which already made and implemented CSR program year by year, the main problem is inefficient CSR implementation that make difficult to shared gain or shared value between stakeholders and company that one of problems from implementation stakeholder engagement. The problem also begins about the standardization of CSR, so that is making harder to solve social conflicts, although the company has been success to achieve PROPER within 2012 and 2013 for PT. Semen Indonesia (Semen Gresik) in Tuban (Semen \& Sustainability, 2017) 


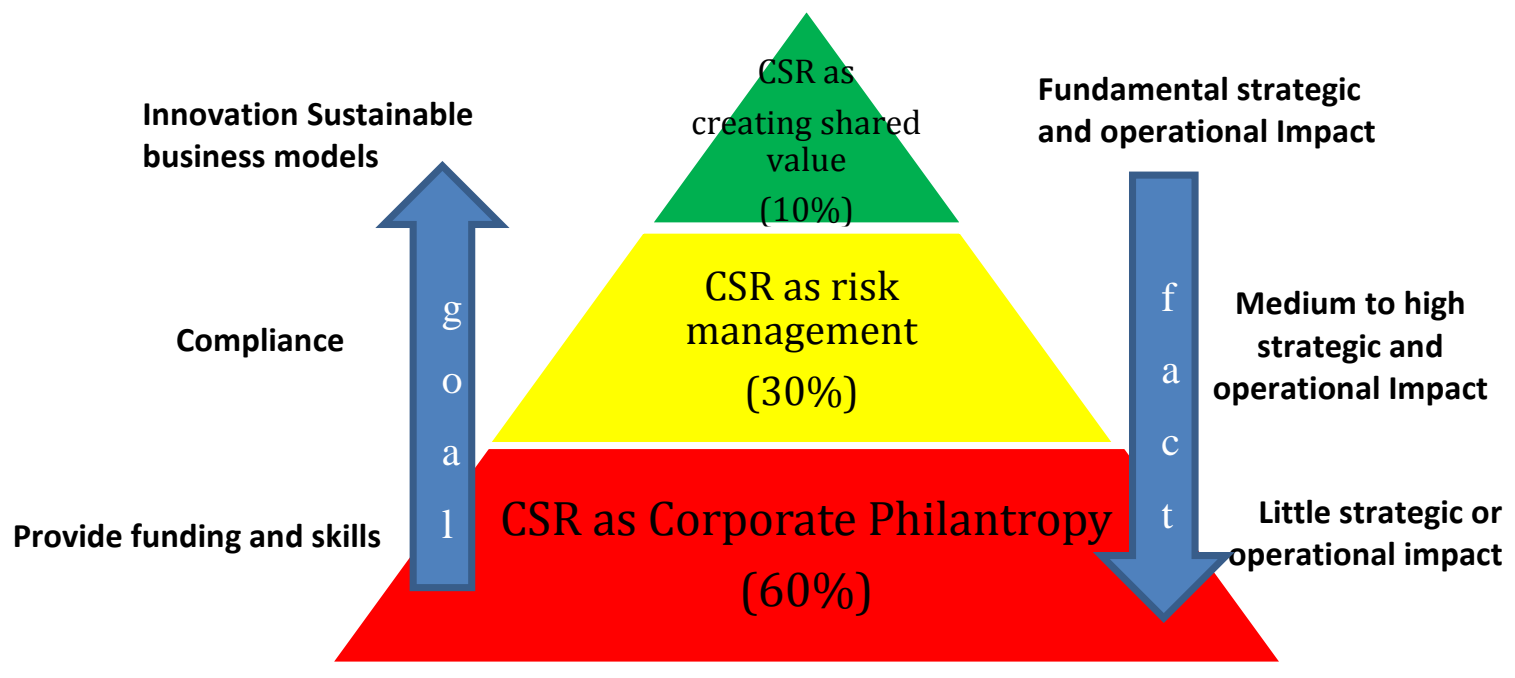

Figure 1.1 PT. Semen Indonesia's CSR or CDI Hierarchies

Source: Semen Indonesia Sustainability Report, 2018

For implementing CSR program, PT. Semen Indonesia explains CSR as creating shared value is community programs that related with sustainable relation and development within company and stakeholders and this hierarchy only grab $10 \%$ of the result of CSR program. CSR as risk management is community program to prevent the social dynamic that probably will disturb the business process and this hierarchy only grab $30 \%$ of the result of CSR programs. In the last hierarchy, CSR as corporate philanthropy is community program that includes community charity with unexpected of return from stakeholder is only one-way services. This program is practically not important, but it's just giving little impact for the company (Semen Indonesia, n.d.).

As one of the largest state-owned enterprises in Indonesia, PT. Indonesian cement gets heavy burden in their responsibilities to the surrounding environment. Moreover PT. Semen Indonesia is a company that processes natural resources have a variety of risks in the future. As well as the selection of CSR programs that are less targeted and sometimes still pegged to program the previous year, the pattern of communication between internal and external parties is often problematic and their different understanding between departments on CSR objectives is also not so good. It is all due to companies that are not obedient and discipline towards standardization that should be used (Muhammad \& Rudito, 2013). Although, PT. Semen Indonesia has already implemented ISO 26000 since 2012 as guidance of CSR, but the company didn't completely adopt standardization into their business process. ISO 26000 clauses definitely will help the company align the goal or objective of CSR. Based on that problems, there is a root cause will be observed more intent in this research which is PT. Semen Indonesia is no obedient and discipline with CSR's guidance (ISO 26000).

\section{Problem of Stakeholder Engagement and Social Conflict}

Stakeholders are one of the entities in the implementation of CSR as a receiver or manager of the company assistance. In the implementation of CSR is the case is still often associated with charity, where CSR is only valid in the time. It obviously will cause a short relationship between the stakeholders and the company, so there will be no ongoing relationship patterns. If this continues it is not likely that there will be social problems in the future, the absence of engagement between the two is the main cause (Carroll et al., 2004). With the target 
company continues to increase, and then the company should pay attention to stakeholder engagement. This is to mitigate the risk of future conflict in the future. Based on that problems, there is a root cause will be observed in this research, PT. Semen Indonesia didn't engage stakeholders and mitigate the social risk properly

The Stakeholder approaches will be effectively implemented in corporate strategic, when its begin to synergy and engage with the company. Stakeholder engagement is the process by which an organization involves people who may be affected by the decisions it makes or can influence the implementation of its decisions. Moreover, the logic of stakeholder engagement in the organization or within the community in which it operates, hold relevant official positions or be affected in the long term. Stakeholder engagement is a key part of corporate social responsibility (CSR) and achieving the triple bottom line.

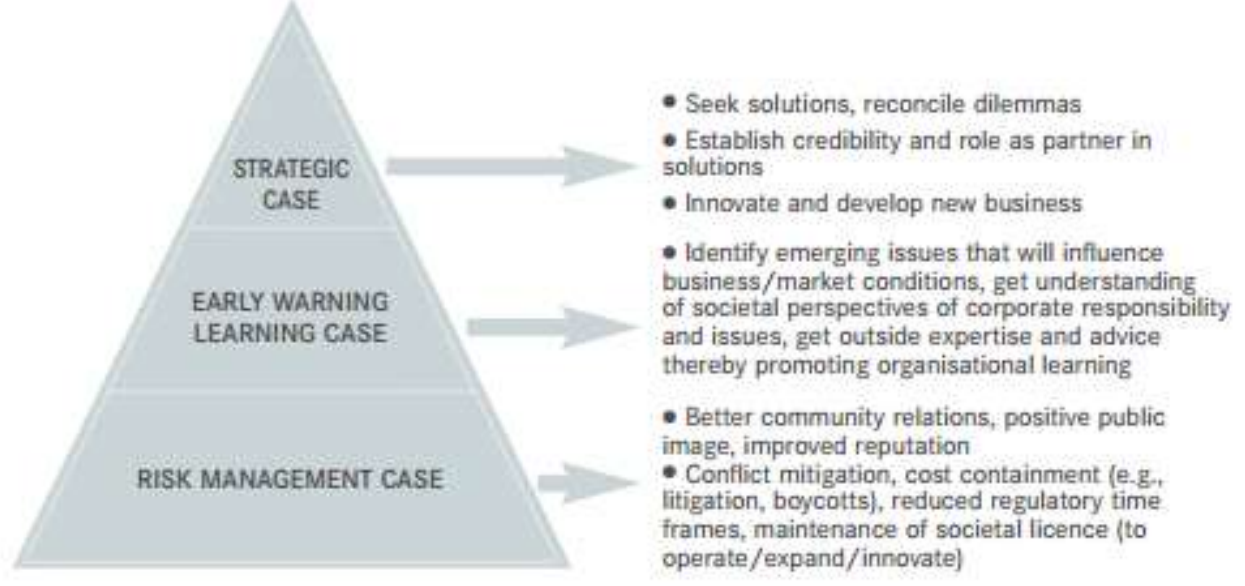

Figure 1.2 The Business Case for Stakeholder Engagement:

From Risk Management to Strategic Positioning

Source: UNEP and Account Ability 2005

The figure above shows hierarchy of business case of stakeholder engagement that will be use for analysis concerns for the alternative solution in this research. Stakeholder engagement will operate in strategy to mitigate the social risk and focus on need of treatment for stakeholders (Gould, 2012).

\section{Research Method}

This research uses qualitative methods by finding primary data derived from social patrons that have been obtained related to the business activities of PT. Semen Indonesia. This research used in depth interview into 50 patron clients that proved by CSR Department in PT. Semen Indonesia. For analysing problems, this interview will used conducting interview that will be consist on behavior, opinion, knowledge and backgroud in CSR departments and patron clients. On the other hand, the use of secondary data is expected to help determine the right solution to answer the root cause. Those root cause are analysed by 5 whys solving method. 


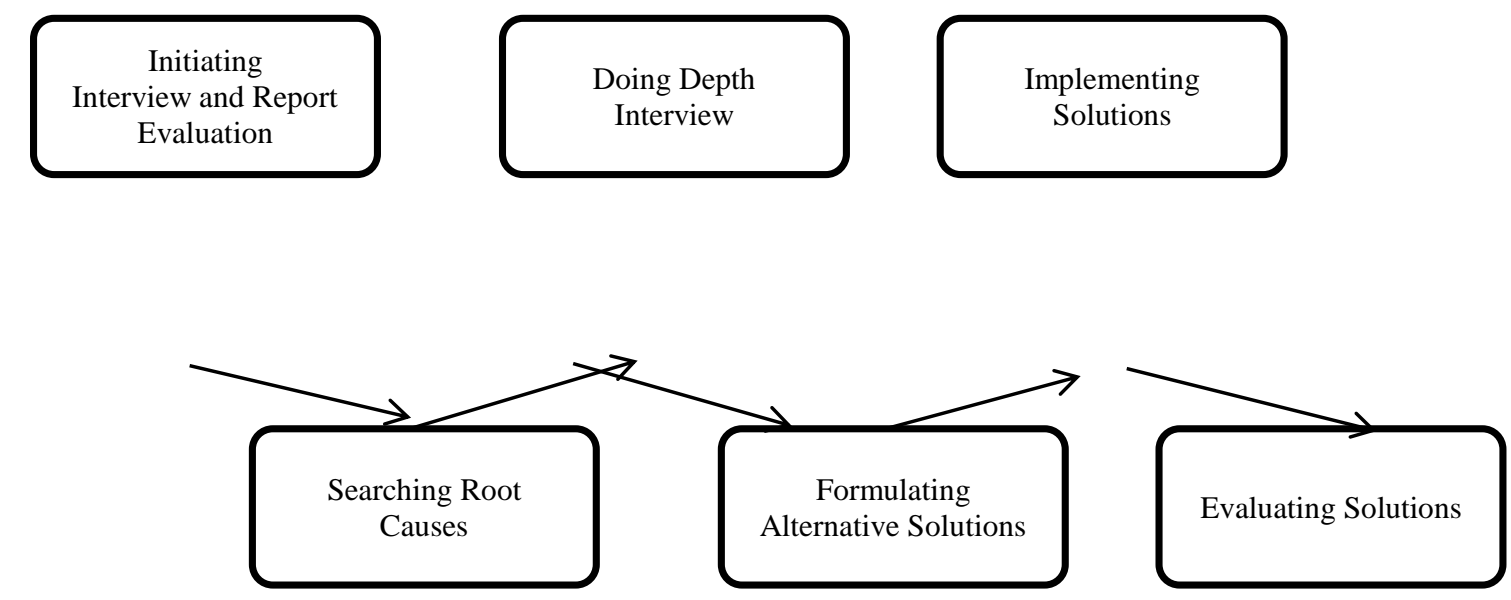

Figure 2.1 Research Methodelogy

\section{Result and Discussion}

For answering the root cause that have been obtained, researcher can use several alternative solutions that can answer the root cause exist. Moreover alternative solutions that can be done in sequence consist of implementation of ISO 26000, commitment and obedience to CSR's objective, Stakeholder Engagement Strategy, adding risk management and early warning conflict in CSR division and Proposed CSR's Business Process (Alves \& Rodrigues, 2018).

\section{Implementation of ISO 26000}

Regarding to ISO 26000 applications, there are seven clauses that showed as outline of the guidance. ISO 26000 provides broad guidance, but does not offer specific instructions or requires for specific outcomes. Businesses that implement ISO 26000 have opportunities to identify and act of their own priorities and to build stronger business models in the spirit of "continuous improvement" (Morris \& Baddache, 2012). ISO 26000 has been applicated in clauses, as follows;

\section{Clause 1 - Scope}

Expanding the scope of CSR is a must for PT. Semen Indonesia who wants to continue to develop into a leading company in Indonesia and in Southeast Asia. Following the company's acquisition of Thang Long Company from Vietnam, the company also had to change the standards that initially only use national standards into international standards by using the standard measurement that used world-class company.

\section{Clause 2 - Term and Definition}

In term of CSR, PT. Semen Indonesia stated key of CSR is how to meet the basic need and want for each stakeholder. Mostly CSR program is misunderstood by concept and meaning, CSR is not only community charity, but also it should create advantages between community and company and it's called creating shared value. That key of terms is nearly suitable with Social Responsibility in ISO 26000 definition, that can be formulated below. 


\section{Shifting Policy (PKBL -> CSR)}

As SOE's, PT. Semen Indonesia can determine CSR programs more effectively

\section{CSR is a business process}

CSR is an important business process to make sustainable development among company and community

\section{Term of CSR}

$80 \%$ of program is about shared-value program

$20 \%$ of program is about charity program

Figure 3.1 Terms and Definition of SR in PT. Semen Indonesia

Source: processed

Clause 3 - Understanding Social Responsibility

Social responsibility is indirectly different from the CSR, where CSR focus more on the way that the form of corporate responsibility is not the case that must be carried out by two interest groups. Moreover, the implementation of social responsibility must be run with the principle of sustainable development. Sustainable development itself is growth and changes that maintains and improves the natural environment, human resources, and society upon which we depend. Businesses that identify maintain and improve their natural and human resources are highly competitive.

\section{Clause 4 - Principles of Social Responsibility}

Those principles must have been implemented by PT. Semen Indonesia with standard measurement that been used before. The problem might be occurring when the implementation of principles is optimal or not. During now, the company has many tools (social mapping) to maintain those principles optimally, even still have a problem in implementation.

\section{Clause 5 - Recognizing Social Responsibility and Engaging Stakeholder}

This clause has been clearly stated in last chapter within the definition and objective. Other concern about the willingness of company to use stakeholder engagement also has been explained.

\section{Clause 6 - Guidance of Social Responsibility Core Subjects}

This clause has elaborate core subject that is effect in the company. Company should determine the level of achievement to fulfill this core subject that is included, as follows: 


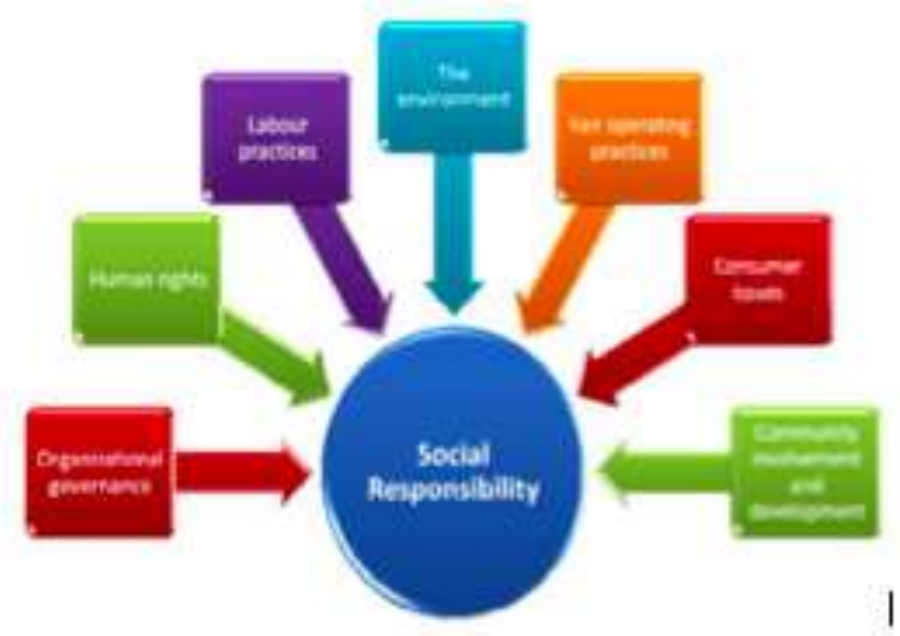

Figure 3.2 Core of Social Responsibilty Source: ISO 26000

Clause 7 - Guidance on Integrating Social Responsibility throughout an Organization

This clause will be elaborate an important and effective means of integrating social responsibility throughout the organization is through the organization's governance, the system by which its decisions are made and implemented in pursuit of social responsibility's objectives. PT. Semen Indonesia should conscientiously and methodically manage its own impacts associated with each core subject and monitor the impact of the sphere of influence within company and stakeholders to mitigate the risk of social and environmental harm. When making decisions, company should consider the best ways to make good programs with minimizing the harmful impact of its program. The company also should confirm that the principles of social responsibility are applied in its governance and reflected in its structure and culture. It should review procedures and processes at appropriate intervals to make sure that they take into account the social responsibility of the organization.

\section{Commitment and Obedience to Social Responsibility's Objectives}

CSR or SR has been understood by CSR department, but its not always be understood by other department and employees. So that, in-specified period, PT. Semen Indonesia that is led by Head CSR department should be held a meeting between other department leader periodically and continuously. For example, held a meeting in every 3 months after reporting period with Board of Director that it is can be tentative but it is necessary. Openness of social responsibility programs with other department is quite good for brainstorming an idea of programs that probably can be met understand each other and build the togetherness within department. Informing is can bring togetherness can bring build a trust about budgeting and implementation program. For implementing social responsibility, the synergy of interdepartmental and intradepartmental is important for building harmonization in terms of problem or conflict occurred (Carroll et al., 2004).

Commitment and obedience can be enhance the PT. Semen Indonesia's credibility that shows as good organization to be exemplified for other organization or company for being good in social responsibility. Other advantages are still maintain company's status as market leader in the Indonesia cement industry that was fully committed for social responsibility, chance to get awards again (Gold PROPER), getting attention from stakeholder who is respected to 
company and good annual reporting to improve corporate's image. In general, the selection of social responsibility programs must be driven by the core subjects and issues in accordance with ISO 26000, particularly in community development and involvement. Then the setting of assistance's priorities for each ring (ring 1, ring 2 and ring 3 ) contained in the production area is required.

\section{Stakeholder Engagement Strategy}

Thought patron clients from government, civil society and the private sector play an important role in creating and maintaining business value (Gould, 2012). As their influence evolves, companies must take a strategic and structured approach to stakeholder relations. To maintain influences that are possible raise some problem for company, this stakeholder engagement strategy below will guide the company to set strategy.

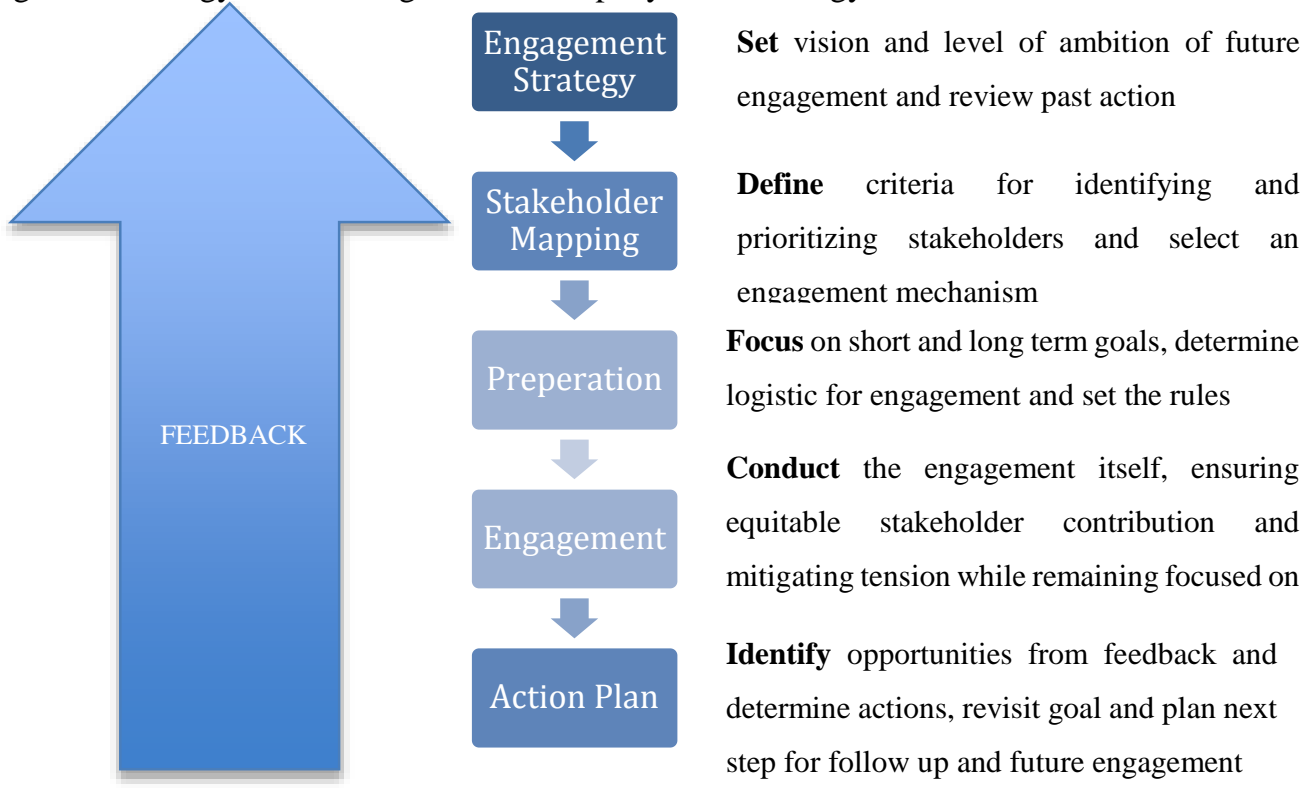

Figure 3.2 Five-Step Approach of Stakeholder Engagement Strategy Source: Processed

This stakeholder engagement strategy has used to mapping stakeholder in PT. Semen Indonesia, Tuban. Based on stakeholder mapping, that include stakeholder information, stakeholder issues, stakeholder engagement analysis and stakeholder treatment (Smith, 2017). Through the tables that have been made, the interview process and direct observation show the following results:

Table 3.1 Stakeholder Engagement Mapping 


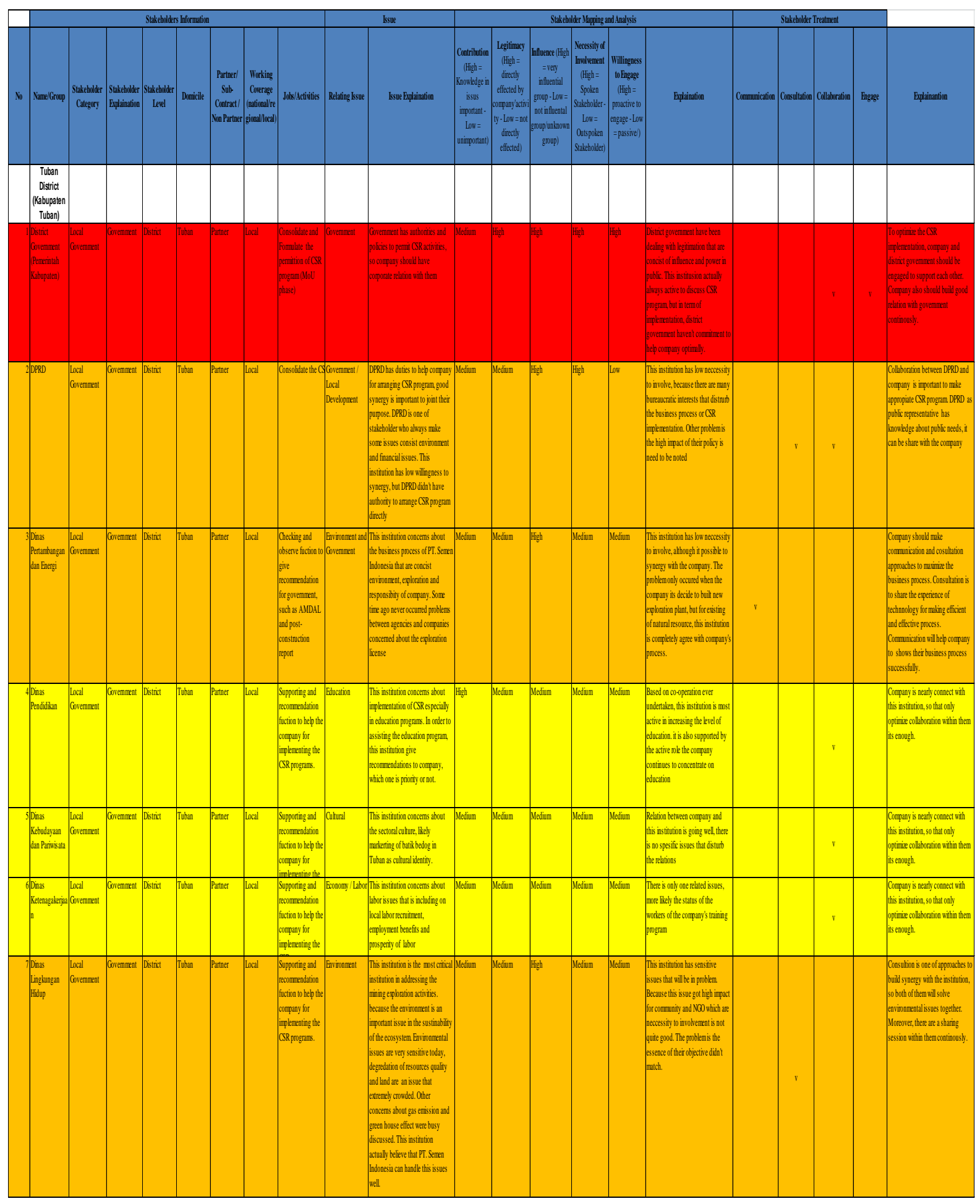




\begin{tabular}{|c|c|c|c|c|c|c|c|c|c|c|c|c|c|c|c|c|c|c|}
\hline $\begin{array}{l}\text { 8Dings } \\
\text { Pertaninan }\end{array}$ & \begin{tabular}{|l} 
Loxal \\
Governmant
\end{tabular} & Covermment & Distint & Thaban & Patner & Loval & 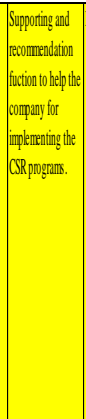 & Envionnent & 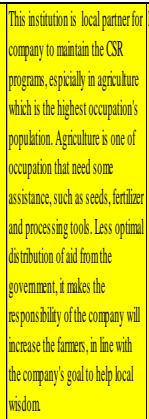 & & Medium & Medium & Medium & Medium & 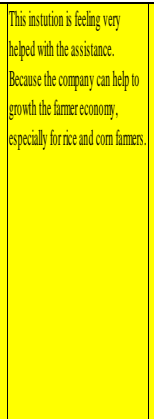 & & 8 & 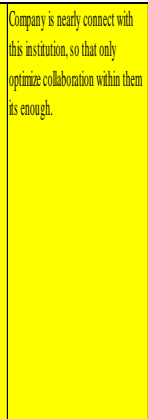 \\
\hline $\begin{array}{l}\text { 9Dinas } \\
\text { Kesechatarn }\end{array}$ & \begin{tabular}{|l} 
Local \\
Covernment
\end{tabular} & Govemnent & Dsiticit & Thaban & Partner & Local & 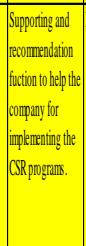 & Heath & 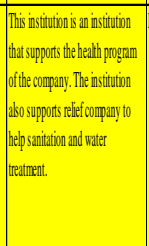 & Medium & Mediun & Medium & Medium & Medium & 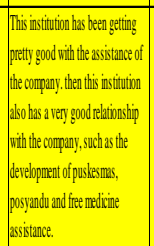 & & $\gamma$ & 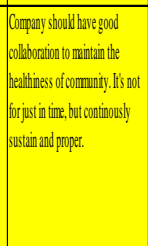 \\
\hline $\begin{array}{l}\text { 10DDinss } \\
\text { Perindustrian }\end{array}$ & $\begin{array}{l}\text { Loxal } \\
\text { Covernmatt }\end{array}$ & Government & Distint & Truban & Partner & Local & 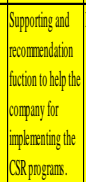 & Loxalecononiny & 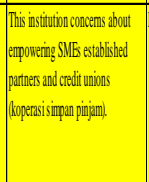 & Medium & Medium & Medium & Medium & Medium & 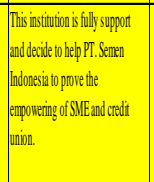 & & $\gamma$ & 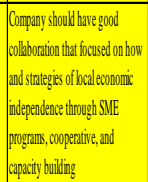 \\
\hline 11 Dinas Petrema & Covernment & Govemnnt & Distint & Thaban & Parther & Loval & 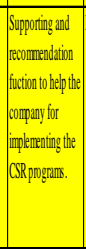 & Loxaleconony & 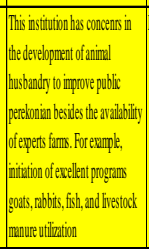 & Medium & Mediun & Medium & Mediun & Medium & 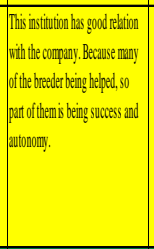 & & $\gamma$ & 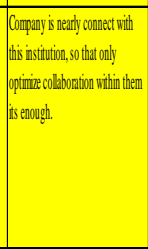 \\
\hline 12/TN/KORAM & Niseruing frece & $\sqrt{\mathbb{N}}$ & Distinit & Thaban & Parther & Loval & $\begin{array}{l}\text { Operational } \\
\text { secunity of } \\
\text { company }\end{array}$ & $\begin{array}{l}\text { Serunity } \\
\text {. }\end{array}$ & 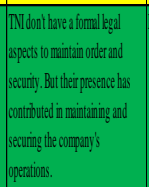 & Medium & Low & Medium & Low & Lan & 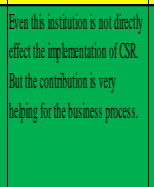 & & 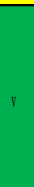 & 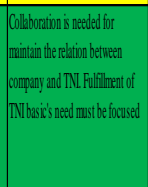 \\
\hline $\begin{array}{l}\text { Polisel } \\
\text { POLRES }\end{array}$ & Secuing firee & Prike & Distitit & Trban & Partarer & Loval & $\begin{array}{l}\text { Operational } \\
\text { secunity of } \\
\text { company }\end{array}$ & Serunity & 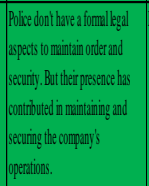 & Medium & Lor & Medium & Low & Low & 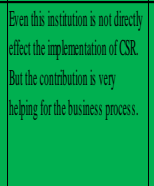 & & $y$ & 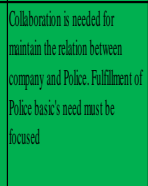 \\
\hline 1HCAGAR & NoO & \begin{tabular}{|l} 
Erivonnmita \\
|NoO
\end{tabular} & Distint & Thaban & Non-Pattreer & thocal & 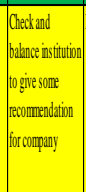 & Enivonnent & 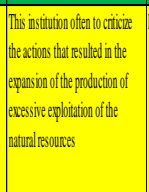 & Low & LWw & High & Low & Low & 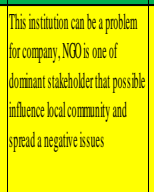 & V & & 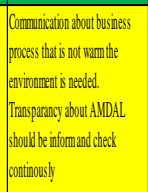 \\
\hline 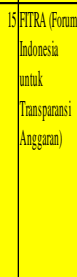 & $\mathrm{m} 100$ & Social NOO & Distint & Thaban & Non-Partner & Local & 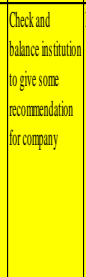 & Loxaleconony & 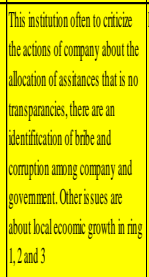 & Low & Low & Hight & Low & Law & 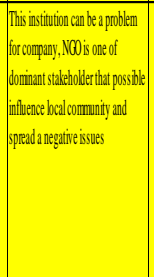 & 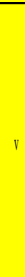 & & 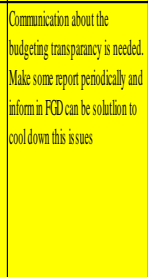 \\
\hline $\begin{array}{l}\text { IfPROPRER } \\
\text { Addisior }\end{array}$ & Goverminth & $\begin{array}{l}\text { Gremment } \\
\text { Isistitionss }\end{array}$ & Natinnal & thatidis & Nori-Purtarer & 4 .rational & 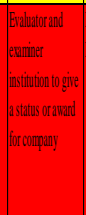 & 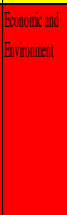 & 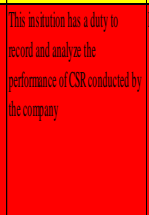 & Lor & High & Highth & Figh & Lan & 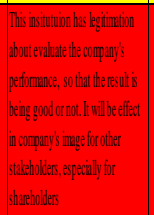 & & & 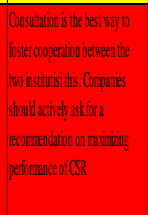 \\
\hline $\begin{array}{l}17 \text { Mangove } \\
\text { Canter }\end{array}$ & Pinyate & $\begin{array}{l}\text { Erivomentit } \\
\text { Coupp }\end{array}$ & Lxal & Thaban & Partner & Lowal & 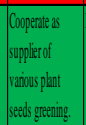 & Erivonartit & \begin{tabular}{|l|} 
This insitution focused to suppy \\
plant seds for CSR's \\
inplementitation
\end{tabular} & High & Lor & Medium & Medium & High & \begin{tabular}{|l|} 
This insitutuon is indenpendent, \\
ever between conpany and \\
institutuon has nutual copounte.
\end{tabular} & & & 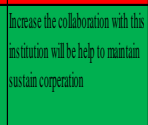 \\
\hline
\end{tabular}




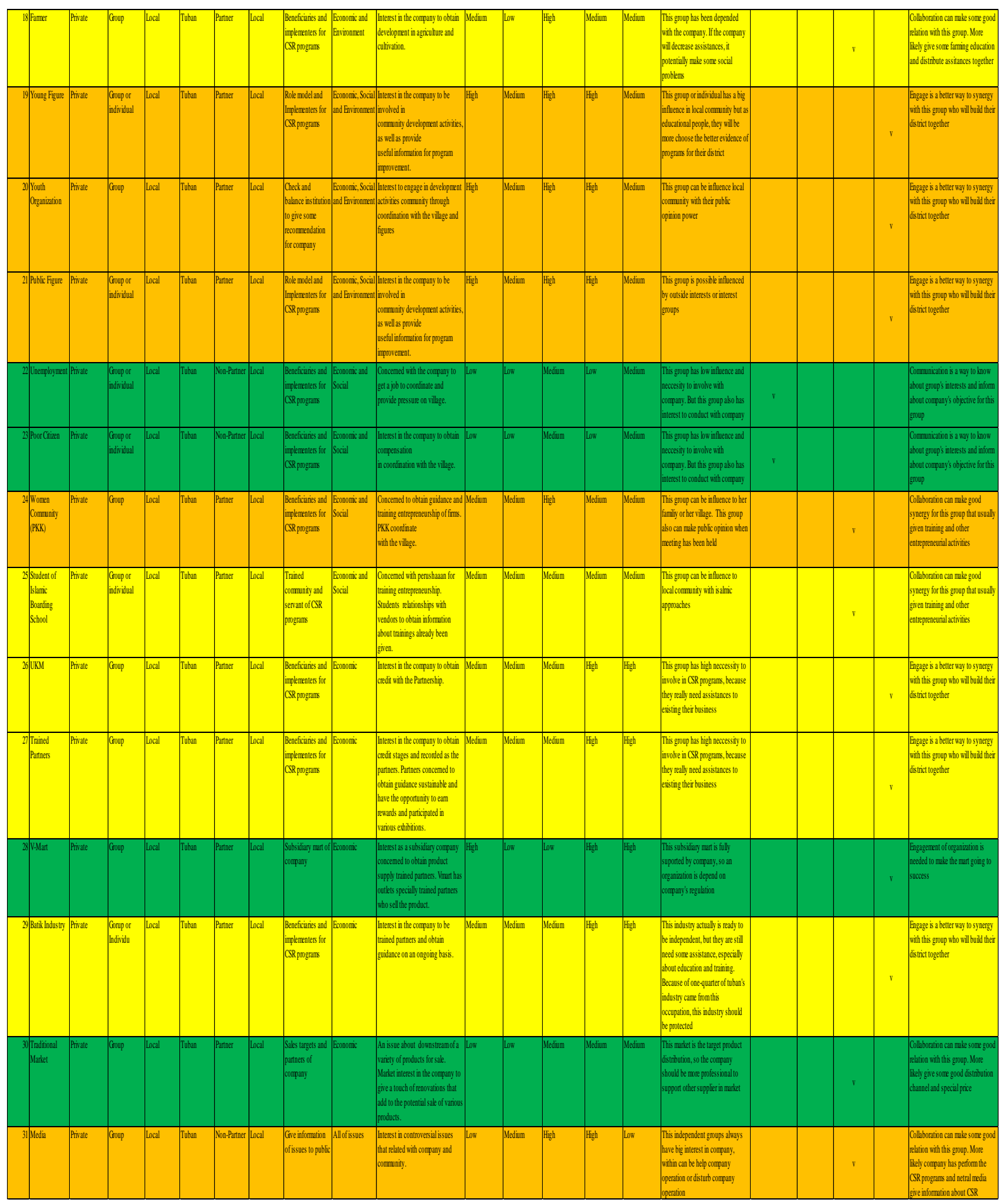


That table above shows basis of termination in each color indicators. Regarding to risk measurement is being use for early warning conflict approach as social risk management. Subsequently potential conflict showed about change of trend among policies or issues and level of issues. 


\section{Additional Risk Management and Usage of Early Warning Conflict as Social Risk Management}

Consist on stakeholder engagement in table 3.8, to make early warning conflict, there are four colors that shown as a sign of level of risk that potentially make conflict. Early warning conflict also will give a response for every change, such as politic, social or economic in every issue. In term of time is possible effect level of change intensity, more likely local election that can change local policy about stakeholder need and want from CSR's assistances (van Walraven \& van der Vlugt, 1996). PT. Semen Indonesia can use early warning conflict for first alarm. Each types of risk should be attention and need to get a more intense treatment. Adding Bureau which is Risk Management Bureau, this bureau should manage any type of risk, such as disaster/accident risk (earthquake, etc), compliance risk (scandal, bribing, etc) and business strategy risk (decision making and policy). This bureau being used for supporting that can be work together with CSR department to mitigate risk. The difference is CSR department has been focused in CSR programs, when Risk Management Bureau has been worked in stakeholders or CSR process.

\section{Proposed Business Process}

For implementing the alternative solution will bring new business processes in terms of the CSR operation, as follows;

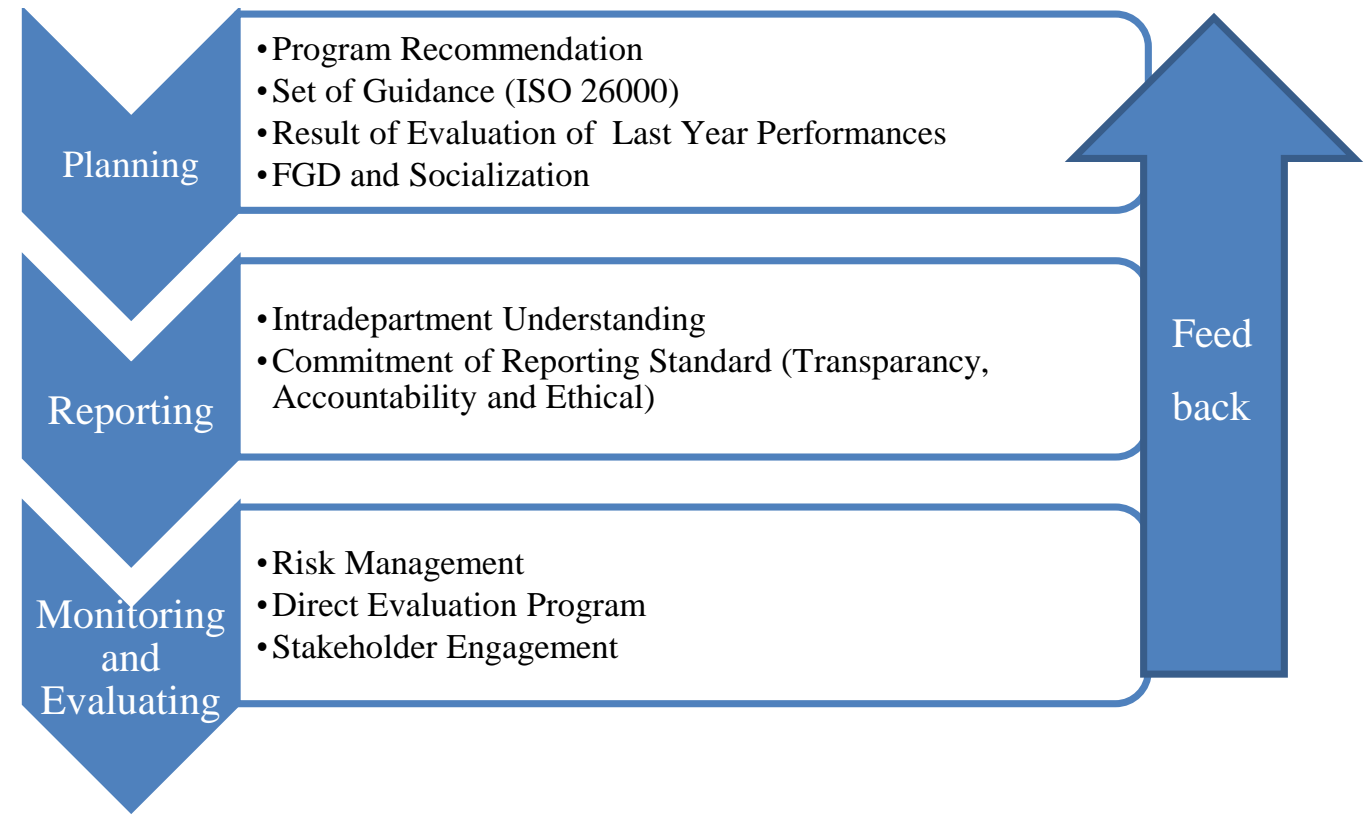

Figure 3.3 Proposed Business Process

That proposed business process is an initial action for PT. Semen Indonesia to maximize the implementation of CSR. Those steps in business process are core process in CSR management that planned in CSR blueprint, but with any adding proposed process that should be passed by company. 


\section{Conclusion}

Those alternative solutions give some benefit for company; first application of ISO 26000 gives guidance for company to set up appropriate CSR program. After PT. Semen Indonesia to be a multinational company, ISO 26000 as international guidance will be making good company's image. Create continuously understanding of CSR in intra-department can make continuous synergy among department. One single business process is not only should be covered by one department but all departments should know objectives and processes to increase togetherness.

Commitment and obedient in CSR's objective can help to implement various components of CSR department. Selection of CSR program that aimed at sustainable development will be depend on PT. Semen Indonesia, but if the selection is suitable with sustainable development, many long term's goal can be achieve. Stakeholder engagement strategy is useful to prevent the social problem about issues and treatments. The level of stakeholder mapping is possible to be changed as well as company's perspective.

Risk Management Bureau can help company to determine risk among community or environment. This bureau also gives recommendation for the top management about risk of implementation of CSR. Moreover, early warning conflict can be first alarm for company to prevent stakeholder or operation area risks.

\section{References}

Alves, M. do C. G., \& Rodrigues, M. M. M. (2018). Corporate Social Responsibility. Corporate Social Responsibility, (4), 1135-1154. https://doi.org/10.4018/978-1-5225-61927.ch058

Carroll, A. B., Marie, J., Sever, M., Ulf, K., Nielsen, U., Pohl, M., \& Hawkins, D. E. (2004). Corporate Social Responsibility - Doing the Most Good for Your Company and Your Cause.

Gould, R. W. (2012). Open innovation and stakeholder engagement. Journal of Technology Management and Innovation, 7(3), 1-11.

Gussman, S. Y., Fathonah, S., \& Wibawa, A. (2009). Analisis Community Development Pt. Telkom Kandatel Yogyakarta Dalam Pengembangan Ukm Melalui Program Kemitraan. Jurnal Ilmu Komunikasi, 7(1), 16-28.

Morris, J., \& Baddache, F. (2012). How to Make Stakeholder Engagement Meaningful for Your Company. Http://Www. Bsr. Org, (January).

Muhammad, A., \& Rudito, B. (2013). PROPOSED APPROACH TO DEVELOP CORPORATE SOCIAL RESPONSIBILITY ACTIVITIES AT KSO PERTAMINA DEPOT CIKAMPEK 2 . B usiness Is ssue Explo oration. 2(3), 272-277.

Semen Indonesia. (n.d.). Laporan Tahunan 2018, Accelerated Transformation.

Semen, P. T., \& Sustainability, I. (2017). Pt semen indonesia sustainability report 2017. 1-110.

Smith, P. A. (2017). Stakeholder Engagement Framework. Information \& Security: An International Journal, 38, 35-45. https://doi.org/10.11610/isij.3802

van Walraven, K., \& van der Vlugt, J. (1996). Conflict Prevention and Early Warning in the Political Practice of International Organizations. 88. 
